\title{
The Humanitarian Gap in the Global Sanctions Regime
}

\author{
Assessing Causes, Effects, and Solutions
}

\author{
Grégoire Mallard \\ Department of Anthropology and Sociology, Graduate Institute \\ of International and Development Studies, Geneva, Switzerland \\ gregoire.mallard@graduateinstitute.ch
}

\section{Farzan Sabet}

Global Governance Centre, Graduate Institute of International and Development Studies, Geneva, Switzerland

\author{
Jin Sun \\ Department of Anthropology and Sociology, Graduate Institute \\ of International and Development Studies, Geneva, Switzerland
}

\begin{abstract}
Since the late 1990s, targeted sanctions and general humanitarian sanctions exemptions have aimed at avoiding the disastrous humanitarian consequences of comprehensive sanctions. In parallel, global banks in charge of administering the international trade of vital goods (food and medicine) have received guidance on how to implement risk-based approaches to avoid completely blockading sanctioned jurisdictions. But these efforts have failed. This article asks: Why has the governance of sanctions and sanctions exemption failed, and what can be done to fix the problem? It argues that a hybrid form of governance in the field of sanctions is responsible for current humanitarian problems. Based on more than eighty interviews with treasury officials, sanctions experts, compliance officers, and others, and taking the international trade of vital goods in Iran as an example, this article assesses various fixes to the governance failures and solutions to address the payment problems that exporters of vital goods in sanctioned jurisdictions face.
\end{abstract}




\section{Keywords}

financial sanctions - targeted sanctions - anti-money laundering (AML) - counterproliferation financing (CFP) - humanitarian exemption - Iran - United Nations Security Council (UNSC) - U.S. Foreign Policy

\section{Introduction}

The debate around the humanitarian consequences of economic sanctions is, by now, an old one. ${ }^{1}$ It first arose in the context of the increased post-Cold War willingness to sanction states that violated basic norms of international relations. The humanitarian consequences of these sanctions of the 199os and associated corruption scandals like the one surrounding the United Nations' Oil-for-Food Programme in Iraq, ${ }^{2}$ created the impetus for the international community to move from the concept of "comprehensive sanctions" toward "targeted" or "smart" sanctions. ${ }^{3}$ Since the terrorist attacks of September 11, 2001, the United States, European Union (EU), and UN have adopted targeted sanctions against militant nonstate actors involved in terrorist activities, specific branches of governments that provide financial or other assistance to terrorists, and the financiers who move illicit money across international borders through charities, local banks, and hawala systems (i.e., clearing mechanisms widely used in Islamic finance) ${ }^{4}$ In all these initiatives, the sanctioning authorities claim to exclusively target the individuals, firms, banks, and state entities directly implicated in well-established criminal activities: terrorism, participation in armed groups, or nuclear proliferation, among others. ${ }^{5}$ Indeed, since 2006, proliferators' deceitful behavior, as illustrated by Iran and North Korea for decades, convinced the international community to also adopt targeted sanctions against nuclear proliferators. In all these cases, there should be, in theory, no humanitarian consequences of targeted sanctions, as they should not affect the trade in food, medicine, or other basic goods.

However, the paradigm of targeted sanctions has been applied since the mid-20oos in an increasingly comprehensivized manner, as illustrated in the

1 Many scholars have participated in this debate; for a short list, see Hufbauer, Schott, and Elliott 1990, 309; Pape 1997; Cortwright and Lopez 2000, 274; Drezner 1999, 372.

2 Weiss et al. 1998, 320.

3 Biersteker and Eckert 2008, 333; Brzoska 2003; Biersteker et al. 2016, 405.

4 Zarate 2015, 488.

5 Solingen 2012, 403 . 
cases of North Korea, Iran, Syria, and Venezuela. In the case of Iran, this shift from targeted to comprehensivized sanctions took place from 2006, when a new round of limited proliferation-related sanctions were first decided by the UN Security Council, until 2015-2016 when the Joint Comprehensive Plan of Action (JCPOA) negotiated between Iran and the UN Security Council's five permanent members plus Germany $\left(\mathrm{P}_{5}+1\right)$ was implemented. During that time, Western sanctions gradually became more comprehensive in scope, especially as the United States and the EU decided in the early 2010 s that Iran's oil exports served to fund its nuclear program, and Iran's oil exports, the shipping companies that carried oil out of the country, and the banks that managed oil-related payments deserved to fall within the scope of targeted and sectoral sanctions. As a result of Iran's dependence on oil exports, the impact of such sanctions has grown to cover virtually every aspect of the economy. Still, today the consequences of the comprehensivization of targeted sanctions in the zolos on the trade of vital and humanitarian goods have only just started to be understood.

From scattered but consistent evidence, we can no longer assume that the current system of sanctions does not interfere with the international trade of vital goods, especially after the US decision to end the JCPOA-related sanctions relief for $\operatorname{Iran}^{6}$ and the escalation of sanctions against Venezuela, ${ }^{7}$ Syria, ${ }^{8}$ and North Korea, ${ }^{9}$ to cite just a few examples. After the US resumption of sanctions against most Iranian banks and the May 2019 decision to sanction all Iranian oil exports, there is good reason to believe that US sanctions against Iran will severely affect the flow of vital goods. Reports from the previous round of sanctions against Iran showed that comprehensivized targeted sanctions created shortages of medical supplies, including in cancer and multiple sclerosis treatments, in a sector in which imported medical supplies accounted for 30 percent of Iran's $\$ 3$ billion pharmaceutical sector. ${ }^{10}$ With the US reimposition of sanctions in May 2018, this story is once again playing out. ${ }^{11}$ For example, a November 2018 analysis by the Society to Support Children Suffering from Cancer (MAHAK), the only charity organization dedicated to children with cancer in Iran, revealed shortages and large prices increases for oncology drugs that "will inevitably lead to a decrease in survival of children with cancer,"12 -

\footnotetext{
$6 \quad$ Motevalli and Nasseri 2018.

$7 \quad$ Kurmanaev and Krauss 2019.

$8 \quad$ McDowell 2018.

$9 \quad$ World Food Programme 2019.

10 Given that sanctions were only recently reimposed, and take time to play out, there are as yet few studies of this impact. Batmanghelidj and Hellman 2018.

11 National Iranian American Council 2018.

12 Kheirandish et al. 2018.
} 
to the point that MAHAK would no longer be able to support the treatment of the 3,500 children with leukemia that they treat every year. ${ }^{13}$ Shortages and cost increases not only affect pharmaceuticals, but also medical equipment, such as radiation treatments in Iranian hospitals, ${ }^{14}$ as well as food imports such as meat, eggs, and milk ${ }^{15}$ —not to mention a vast range of other goods and services falling under the broader categories of "humanitarian trade," and "humanitarian finance," that are important for issue areas from access to water to airline safety, to environmental conservation and disaster relief, which are key in the postflooding context in Iran. ${ }^{16}$ The international community must act to find a solution if it is to avoid the risk of severe humanitarian crises in sanctioned jurisdictions, whether in Iran or elsewhere, and the migration flows and related consequences that can result.

In all sanctioned jurisdictions, the mismanagement and corruption of local governments contribute to the deterioration of humanitarian conditions, but the evidence clearly points to a steadily worsening humanitarian situation due to the comprehensivization of sanctions, the scenario that targeted sanctions were precisely designed to prevent. ${ }^{17}$ Such negative effects, we show, are largely due to global banks' reluctance to conduct repeated risk analyses for each transaction involving individuals or companies in sanctioned jurisdictionsthe "risk-based approach" to sanctions implementation. In the Iranian case, as repeatedly mentioned by many sanctions experts and compliance officers who we interviewed for our research, ${ }^{18}$ banks have largely abandoned the riskbased approach in favor of a "zero-risk" approach to Iranian payments, including those related to the humanitarian trade. Banks' demonstrated aversion to administer payments from Iran has created a bottleneck in the trade in vital goods, which has disrupted the supply chain from foreign manufacturers to patients, particularly for the most advanced medicines. Such risk aversion is due to multiple factors such as the increasing complexity of determining which entities are legitimate and which are not in a sanctioned jurisdiction,

\footnotetext{
13 Qiblawi, Pleitgen, and Otto 2019.

14 Ghalibafian, Hemmati, and Bouffet 2018, e58o.

15 Saul 2018.

16 Sregantan 2018.

17 Farzanegan et al. 2016.

18 This article is based on about eighty interviews with compliance officers in global banks, US and European sanctions specialists, and financial regulators working in international organizations, as well as participation in six multistakeholders conferences on the topic of Iran's financial hurdles in the post-JCPOA era (from 2016 to 2018), and on other countryspecific cases of sanctioned jurisdictions.
} 
the unwillingness demonstrated by public regulators to share the burden of responsibility with regard to sanctions implementation, and the fact that most Tier 1 and Tier 2 banks in Europe do not want to risk being fined by US authorities and being excluded from the US market.

Another, complementary, explanation points to the lack of consensus among regulators over the scope of sanctions exemption and the vagueness of the notion of "humanitarian exemption" for most public authorities, in particular the US government. Indeed, "humanitarian goods" can be restricted to food or medicine, or include goods that fall under sanctions lists such as oil or steel, if they are used to alleviate civilian suffering in humanitarian crises. But for some experts, it is entirely the context-for example, the existence of a largescale humanitarian disaster-rather than the nature of the product-food, medicine, or other-that determines whether the good falls under the category of humanitarian, so that there exists no good whose trade can be safely authorized at all times by public regulators. This trend toward a restricted definition of "humanitarian exemption," as remarked by Sue Eckert, can be witnessed in recent US executive orders imposing targeted sanctions against terrorists, which typically revoke broad humanitarian exemptions. ${ }^{19}$ Along similar lines, in the case of Iran sanctions, top US leaders expanded the list of illegitimate business with Iran, as they acknowledged their desire to create "maximum pressure" 20 or inflict "maximum pain" 21 on the country.

With this background in mind, in this article we ask: What is the main source of this humanitarian gap in the global sanctions regime, and how can it be addressed? We argue that reasons for the emergence of this gap are manifold, but can be mostly accounted for by the hybrid and contradictory nature of the present governance of sanctions and sanctions exemption, which combines elements from the transnational form of governance-well articulated by scholars such as Anne-Marie Slaughter or Marie-Laure Djelic ${ }^{22}$ - and other aspects that point to a much less discussed hegemonic form of governance. ${ }^{23}$ This hybridity in the governance regime in the field of sanctions has a strong bearing on the policy prescriptions formulated to fix the humanitarian gap: indeed, the latter go in a different direction if the governance arrangement is

\footnotetext{
19 This has led the Treasury Department and other departments in charge of implementing US sanctions to grant "case-specific [humanitarian] licenses in each sanctions program." Eckert 2017, 17. See also Charity and Security Network 2012.

$20 \quad$ Wroughton and Holland 2018.

21 Nephew 2018, 238.

22 Slaughter 2004; Djelic and Andersson 2006.

23 Mallard 2019.
} 
purely transnational or purely hegemonic, or if it is hybrid (see Table 1). As we explain, if governance was mostly transnational, solutions would mainly seek to help banks reduce the costs of compliance when following risk-based approaches to sanctions implementation. If the governance arrangement was clearly hegemonic, prescriptions would seek to increase the transparency and efficiency of the hegemonic rules; for instance, by asking the US government to transparently formulate the scope of licenses as well as to consider applications to humanitarian licenses from all over the world (see Table 1). But as the governance arrangement of sanctions is hybrid, so we argue, the main threat is the fragmentation of the rules of global trade and the creation of potentially unworkable alternatives, as for instance those formulated in Europe with the Instrument in Support of Trade Exchanges (INSTEX). The creation of INSTEX in January 2019 was intended to prevent the European food or medical trade with Iran from being blocked or falling into the hands of shady financial intermediaries in Europe or Turkey, which usually extract incredibly high fees from the transacting parties and contribute to the sustained opacity of global financial networks. ${ }^{24}$

In this article, we call for an urgent examination of new proposals to facilitate global payments related to trade of vital goods in sanctioned jurisdictions. This is the right time to do so, as most proposals emerging from the policy field are still in their infancy, and sanctions are an increasingly popular tool of economic statecraft seen as a middle ground between and complementary to diplomacy and war. This article contributes to the present policy discussion by assessing the strengths of current proposals in relation to the governance issues they try to solve. We argue that most policy initiatives lack sufficient unity of purpose and scope, and that new solutions should be grounded on a more thorough analysis of the specific problems they try to solve. We thus call for a urgent consideration by all governments of the predicaments encountered by global private banks, which cannot by themselves be left to interpret how sanctions exemptions will be administered because they lack the legal skills and political authority necessary to make decisions affecting the laws of economic warfare and the lives of innocent people in sanctioned jurisdictions. In this context, we call on policy communities to reflect about a new multilateral system for exemptions and new payment technologies.

24 Other factors contribute to civilian hardships, such as hard currency deficits resulting in the collapse of the domestic currency—-here the rial (IRR)—which can lead to a rise in the price of domestically produced generics that rely on imported ingredients. But that kind of problem will inevitably affect all sectors in any sanctioned jurisdiction. 


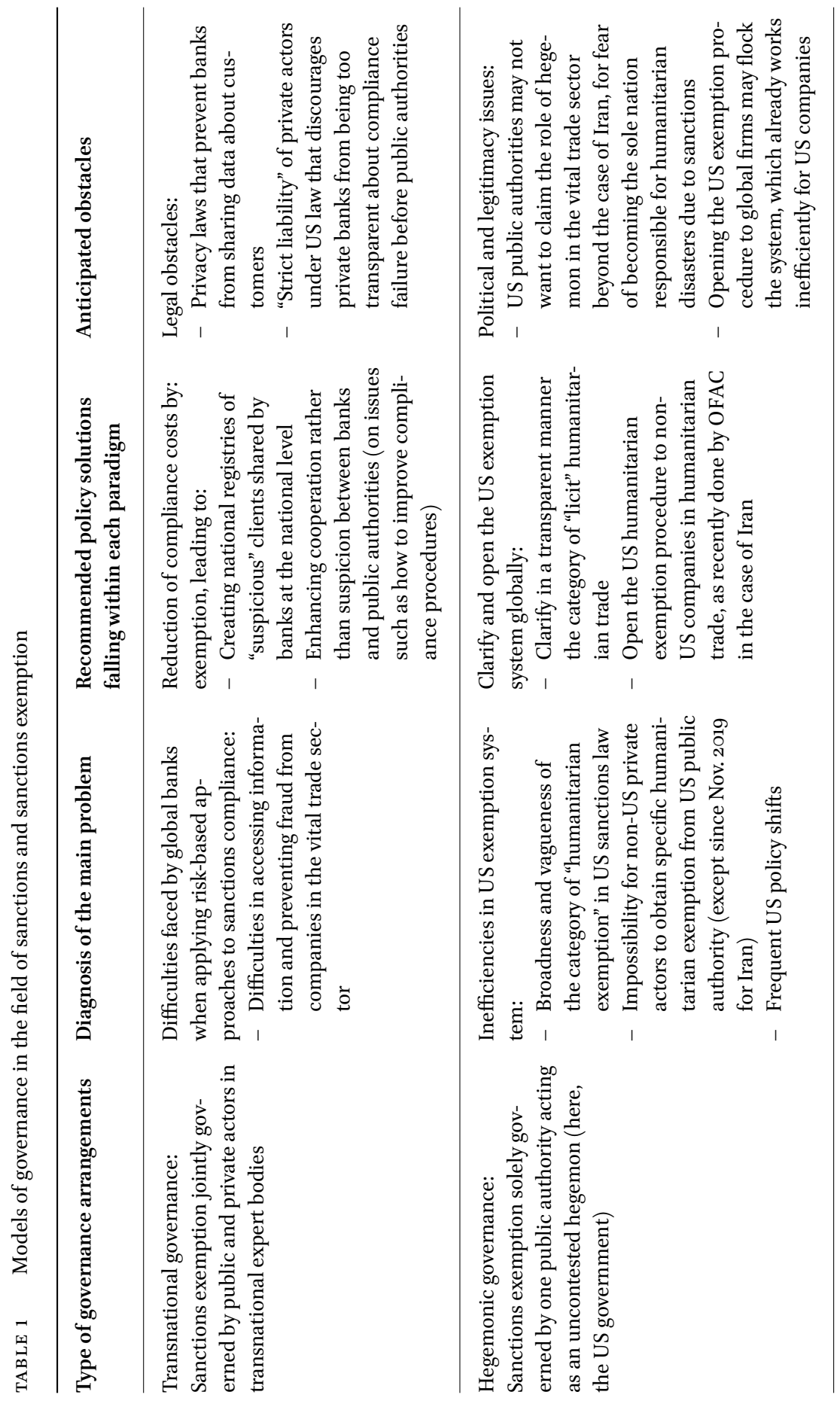




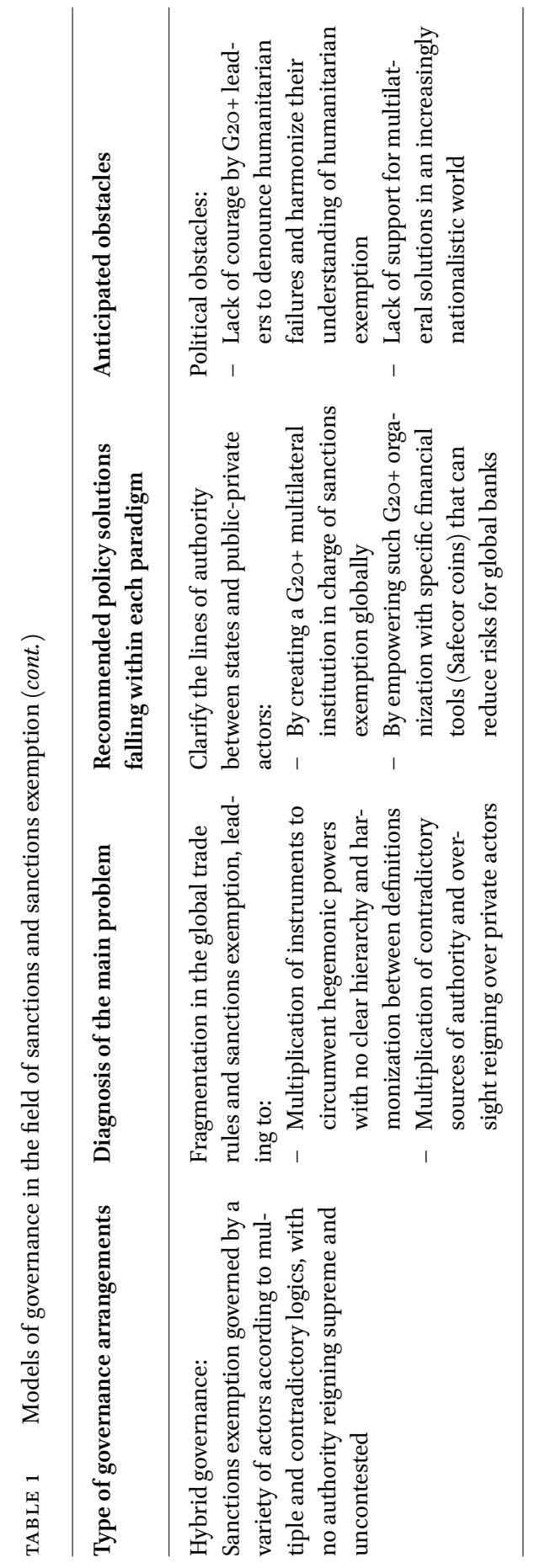


This article is divided into three parts. First, we explain why risk-based approaches have been advanced in the field of sanctions implementation, and why banks have largely failed to implement the latter in high-risk jurisdictions. Then, we examine a range of solutions that have been discussed over the past year or so to help global banks process payments associated with humanitarian trade in sanctioned jurisdictions in less costly ways. We find these solutions inspired by risk-based approaches to sanctions exemption are at best ad hoc solutions that face a number of serious challenges in terms of their long-term viability. Finally, we show why governments need to engage with the US regulatory authorities in charge of sanctions exemption, and that such a political approach is better when embedded in a multilateral rather than bilateral framework. We lay out a blueprint for a new multilateral governance of humanitarian exemptions to sanctions, buttressed by the existence of a new type of nonbanking, digital currency-based, payment mechanism we name Safecor coin. The term Safecor coin reflects the underlying ambition of establishing a safe corridor for humanitarian-related payments in sanctioned jurisdictions and beyond.

2

\section{The Limits of Transnational Governance: Global Banks' De-risking Strategies in the Context of US Regulatory Hegemony}

The global fight against criminal financial activities is conventionally traced back to a myriad of anti-money laundering (AML), counterterrorism financing (CTF) and counterproliferation financing (CPF) initiatives taken by the UN Security Council, Financial Action Task Force (FATF), and International Monetary Fund (IMF), among others. ${ }^{25}$ To many scholars, the strong implication of issue-specific, expert-driven, and voluntary-based international bodies in charge of codifying and diffusing best practices aimed at circumventing financial criminality illustrates the turn from multilateralism to "transgovernmental" or "transnational governance," in which regulation is characterized "by a blurring of the distinctions between public and private actors, states and markets." ${ }^{26}$ For these international organizations (IOs), financial regulators and bankers need to defend the "integrity" of the financial system by the adoption of many new prudential measures that aim at insulating global banks from opaque banks operating in high-risk jurisdictions, especially in territo-

25 Serrano and Kenny 2003.

26 Djelic and Andersson 2006, 5 . 
ries under sanctions. For the past decade, the FATF produced guidelines in the fields of AML, CTF, and CPF, and conducted country audits, which resulted in the attribution of color-coded grades to national banking legislations that can help guide foreign investors and banks to comply with sanctions rules. In this type of governance arrangement, not only are the private banks co-opted into the making and implementation of the rules and the detection of violations, but the IO s in charge of codifying best practices for regulators also place themselves at the service of the industry and law enforcement agencies. From this transnational form of governance of finance, a new order, both legitimate and efficient, is supposed to emerge.

At the same time, from 2006 to 2018 , we can only be struck by how much global banks departed from the best practices and other risk-based approaches of sanctions implementation that the UNSC and FATF have consistently recommended. Instead, after the United States took a series of actions aimed at forcing compliance among global banks that violated US sanctions and committed massive fraud to hide this fact, incriminated European banks completely left any business tied to high-risk jurisdictions such as facilitating payments related to humanitarian trade with sanctions jurisdictions. The United States, and its Office of Foreign Assets Control (OFAC), clearly frightened global banks out of sanctioned jurisdictions such as Iran, especially during the period leading up to the 2015 Iran nuclear agreement. ${ }^{27}$ For over twentyseven banks investigated by OFAC, the Justice Department and New York State Department of Financial Services (DFS), most of them were European banks involved in violations of Iran-related sanctions. Fines skyrocketed over the period; namely, US $\$ 1.92$ billion for HSBC, ${ }^{28} \$ 1.4$ billion for Société Générale, $\$ 1.1$ billion for Standard Chartered, ${ }^{29}$ and $\$ 8.9$ billion for BNP Paribas (see Table 2). ${ }^{30}$

The worldwide regulatory power that the US government has gained from 2005 to 2015 in the field of sanctions enforcement can be explained by two key characteristics of the relations between global banks and the US government. First, the banking sector is directly and indirectly under US regulations due to the centrality of the US dollar to international trade. A transaction can enter US jurisdiction for just milliseconds when a dollar-denominated trade is cleared in New York and becomes subject to this authority. Since 2008, according to an OFAC ruling, this situation gives US regulators and judicial authorities territo-

\footnotetext{
27 Congressional Research Service 2019.

28 Protess and Silver-Greenberg 2012.

29 Crow 2019.

30 Department of Justice 2014.
} 
TABLE 2 Examples of global banks fined by the US government for Iran-related sanction evasion

\begin{tabular}{lll} 
Period & Global bank & Type of violations of Iran-related US sanctions \\
\hline $2009-2010$ & Credit Suisse & Iran, Libya, Cuban, and Sudan sanctions \\
$2009-2010$ & Barclays & Iran, Libya, Cuban, and Sudan sanctions \\
$2009-2010$ & JP Morgan & Iran, Libya, Cuban, and Sudan sanctions \\
$2009-2010$ & Royal Bank of Scotland & Iran, Libya, Cuban, and Sudan sanctions \\
& Group (ABN Amro Holding) & \\
$2010-2012$ & HSBC (mainly in Mexico) & Drug-cartels, but also Iran, Cuban, and Sudan \\
$2010-2012$ & ING & sanctions \\
$2012-2015$ & BNP Paribas & Iran and Sudan sanctions \\
$2010-2012$ & Standard Chartered & Iran and Sudan sanctions \\
$2012-2015$ & Commerzbank & Iran, Libya, Cuban, and Sudan sanctions \\
2017 & Citigroup (Banamex USA in & Iran and Sudan sanctions \\
& Mexico 2017) & \\
Nov. 2018 & Société Générale & Iran sanctions \\
Nov. 2018 & Standard Chartered & Iran sanctions \\
& &
\end{tabular}

rial authority to apply US sanctions law, even to transactions related to trade not taking place on US soil and not involving US entities or persons. ${ }^{31}$ Second, because most human activities depend on banking to facilitate payments or finance new projects, and because so much of the world's banking activities take place in the United States, any US threat to cut a bank from accessing the US financial market because of the maintenance of a tie with a US-designated entity - the US power to impose "secondary sanctions" - can be devastating. For these reasons, the United States, and OFAC, have gained disproportionate responsibility in the administration of sanctions and sanctions exemption.

Global banks' culture of "overcompliance" with sanctions is in large part the outcome of their entanglement with US financial authorities and the lack of clarity of US rules governing sanctions exemptions. Even though the US government insists that it observes a broad humanitarian exemption, all payments in the field of medicine or food that would go to an entity even remotely controlled by a designated entity (for instance, the Iranian Revolutionary Guards)

$31 \quad$ Mallard 2019. 
would constitute a violation of US sanctions law. ${ }^{32}$ Confronted with the risk that due diligence procedures would fail to detect a connection to a US designated entity, global banks have preferred to massively "de-risk" rather than apply uncertain Know Your Customer (KYC), Know Your Customer's Customers (KYCC), and Know Your Transaction (KYT) procedures mandated in the transnational governance of sanctions. Instead, they have dropped customers from Iran and other sanctioned jurisdictions en masse, or not facilitated transactions with correspondent banks of banks located in Iran, even in the humanitarian field.

Risk aversion has increased since 2010 because of three other reasons. First, those global banks that made a deferred prosecution agreement with the US Department of Justice in the early 2010 s are still under strict supervision and monitoring obligations and, in some instances, have explicitly agreed not to transact with sanctioned jurisdictions. Second, global banks quickly saw the risk of high US fines if they engaged with the wrong client in Iran, compared to the lower cost of losing an Iranian client. Banks are, after all, for-profit organizations. Third, US citizens, even when working for a global bank in Europe or Asia, are always under the purview of US law, which means that they would be liable for criminal offenses should they personally provide services to finance Iranian activities without having first obtained the proper license, which banks worldwide do not (and cannot) seek if they are outside the United States. And one cannot but notice that former US governmental sanctions officials, especially those with prior work experience at the Treasury Department, have come to work in the compliance teams of global banks on a large scale worldwide since 2010. These three additional factors explain why the new policy of banks vis-àvis sanctioned jurisdictions such as Iran is not to conduct risk analysis, but to refrain from any commercial relationship with any entity in that jurisdiction.

Overcompliance has not been limited to global banks. Global banks have also increasingly pressured small and medium local European banks, as well as correspondent banks in the Middle East region, to cut ties with Iranian clients and other clients in high-risk jurisdictions. ${ }^{33}$ This pressure is due to global banks' US exposure and fear of the imposition of secondary sanctions if smaller European, Asian, or Arab banks with whom they have banking relations are sanctioned as a result of relationships with US-sanctioned Iranian clients. This outcome is again the result of Europe's global banks' near exclusive concern

$32 \quad$ World Bank 2016.

33 Due to lack of space, we did not mention all of the times our analysis was based on reporting by interviewees, but these kinds of assertions were repeated many times by interviewees during our fieldwork. 
with maintaining good credit in the eyes of the United States and near certainty that there will be no penalty for not engaging in Iran or other sanctioned jurisdictions, despite recent calls by the European Union to adopt "blocking statutes" that would prevent European banks for privileging US law over EU sanctions law. The spread of de-risking practices has been so strong that, as documented by the IMF, ${ }^{34}$ the FATF, ${ }^{35}$ the World Bank, ${ }^{36}$ and the Financial Stability Board (FSB), new measures are needed to curb this trend, which is widely impacting the humanitarian conditions in many countries where remittances serve as an important source of income. ${ }^{37}$ Indeed, the number of active correspondent banking relationships, which reflect demands by local banks typically from the Global South that ask global banks to clear their payments in foreign currencies (typically, US dollars or euros), "declined by $6 \%$ across all currencies between 2011-2016" according to recent data from SWIFT (Society for Worldwide Interbank Financial Telecommunication). ${ }^{38}$ This complex situation can lead the trade of vital goods to simply stop or enter through the black market at significantly inflated prices that line the pockets of shady middlemen or criminals. ${ }^{39}$ This is why risk-based approaches to sanctions implementation will not be enough to fix the humanitarian gap, and new solutions are needed.

Indeed, this new situation has made trade, not to mention investment, in sanctioned jurisdictions highly unlikely. In the case of Iran, even though the JCPOA promised to offer an economic solution to Iran's financial hurdles, between the implementation of the JCPOA and President Donald Trump's decision to leave it, global banks' aversion to risk prevented Iran from reaping many of the benefits of the sanctions relief agreement. Though European companies were supposed to return to the Iranian market and modernize oil production, the Iranian government observed with great worry the problems faced, for instance, by Total, which eventually ended its participation in Iran when President Trump resumed sanctions against the Iranian oil sector. ${ }^{40}$ When, on 5 November 2018, the US government completed the process of reimposing pre-JCPOA sanctions on Iran, including on all Iranian oil, gas, and shipping companies, and forced SWIFT, the international interbank messaging service, to block transfers to most Iranian banks, save a few exceptions,

\footnotetext{
$34 \quad$ Erbenová et al. 2016.

35 Financial Action Task Force 2015.

36 World Bank 2015.

37 Corazza 2016.

38 Financial Stability Board 2017.

39 Borger and Dehghan 2018.

$40 \quad$ Hafezi 2018.
} 
it publicly exposed the fact that the European Union, Russia, and China have been unable to change the calculus of global banks in a highly uncertain policy environment. ${ }^{41}$ Even if the Iranian government passes a set of bills inspired by FATF recommendations through the Iranian parliament to increase the confidence of international banking clients that money coming into their accounts from Iranian banks does not originate from an illicit deal five or six steps prior, it would be surprising if the banking sector changes its attitude toward Iranian payments in the short or medium term, especially considering the recent escalation of the conflict between the US and Iranian governments. ${ }^{42}$

Current Mitigation Strategies Aimed at Strengthening Risk-Based Approaches to Sanctions Exemption

A range of solutions have been proposed with the goal of addressing some aspects of the payments problems encountered by importers of vital goods in sanctioned jurisdictions. Every country seems to agree on the need for continued trade of vital goods with sanctioned states. OFAC has a general exemption license for trade of food, medicine, and goods used for humanitarian purposes. But as said, the devil is in the details, and the difficulties in assessing the ownership structure of companies in Iran and other sanctioned jurisdictions make it hard for a banking compliance manager to safely claim that even payments for medicine will not violate US sanctions, which is why most banks have stopped accepting payments from countries like Iran, Syria, and Venezuela. ${ }^{43}$

European authorities have tried to provide political support for technical solutions that seek to address the humanitarian gap and solve the problem of de-risking. A first array of solutions simply sought to reduce the compliance costs for the banking sector, so that the latter can at long last adopt the riskbased approach advocated by the FATF and IMF. Emerging from various multistakeholders conferences organized on problems encountered by humanitarian nongovernmental organizations (NGOs) in administering payments to sanctioned jurisdictions, which have been organized for instance by the World

41 An additional problem is that Iran generates foreign exchange reserves mostly by selling its oil abroad, which OFAC forbid all but seven countries (five Asian and two European) from purchasing from November 2018 to May 2019-an exemption that had not been renewed as of May 2019 .

42 Sharafedin 2019.

43 As some of our interviewees acknowledged, the mere fact of raising this issue may convince bank managers not to move into Iran-related trade. 
Bank Group, ${ }^{44}$ multiple stakeholders have called for stronger informationsharing and cost-sharing measures. Building on the work of experts, ${ }^{45}$ World Bank reports point to measures that could reduce the costs of KYC procedures: for instance, banks could pool complementary information and avoid running parallel and redundant costly KYC procedures by creating national registries of customers. Although problems would still exist, as the latter may violate privacy laws, these solutions have the advantage of avoiding the politically costly creation of new multilateral institutions aimed at balancing the worldwide hegemony of US sanctions law (see Table 1). Additionally, states could help humanitarian actors by including the costs of enhanced KYC procedures in state-funded aid programs. States could also directly lessen compliance costs by adopting softer punishments in case of banking self-disclosure when inadvertent sanctions violations are reported by banks, in contrast to what presently occurs in the United States. The solutions under discussion also routinely mention moving toward "business-to-business payments," 46 in an effort to cut costs and intermediaries, which could even use new financial technologies such as new blockchain-based digital currencies.

In addition to such measures, a much more ambitious attempt to address the humanitarian gap in sanctioned jurisdictions has come from the three European countries (EU-3, or, France, Germany and the UK), which in January 2019 created a special purpose vehicle (SPV), the Instrument in Support of Trade Exchanges (INSTEX). The mission originally attributed to INSTEX was to protect both European economic sovereignty and the JCPOA from US attacks, although the mandate of INSTEX is now much more limited as it is simply meant to facilitate the trade of vital goods. INSTEX is a clearing mechanism that can be used by banks in Europe and Iran to avoid administering any direct payment from European private companies to private or public entities from Iran. ${ }^{47}$ INSTEX does not send payments from European importers of Iranian food (e.g., pistachios) to European exporters of medicine and food, but merely sends information to European Importer A (of food) that it will send to European Exporter B (of medicine) the money that Importer A owes to Iranian Exporter C (of pistachios). In parallel, INSTEX will also notify the Iranian mirror SPV to instruct Iranian Exporter C (of pistachios) to receive payments from the same amount from Iranian Importer D (of medicine). For INSTEX to work properly, it will always need its Iranian counterpart to also identify Iranian

\footnotetext{
44 International Stakeholder Dialogue 2018, 7.

45 Eckert 2017.

46 International Stakeholder Dialogue 2018, 5.

47 Batmanghelidj 2019.
} 


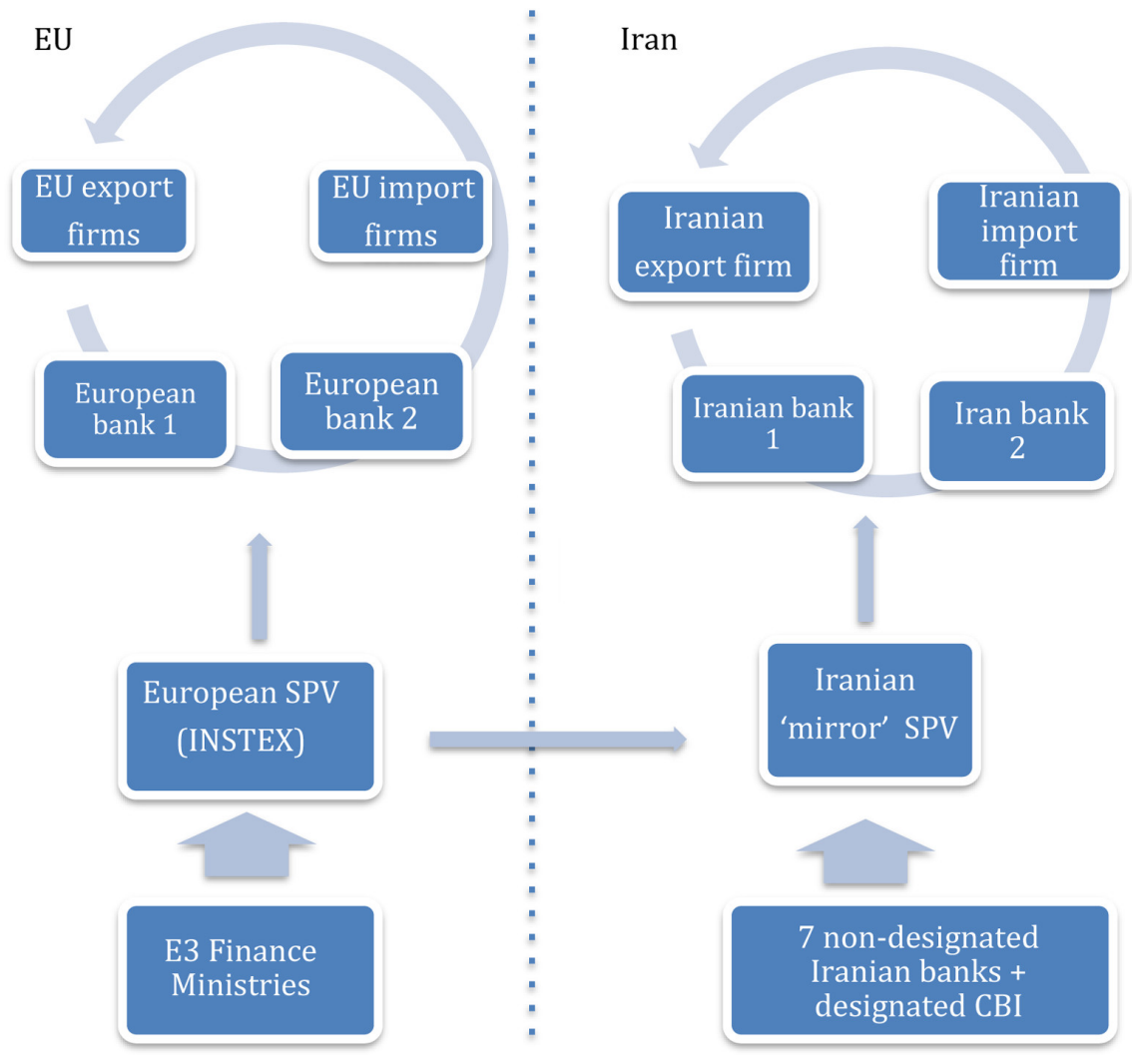

FIGURE 1 How the European special purpose vehicle (SPV) is supposed to work

Note: Here are some explanations of how the SPV would work, in case of consistent trade deficit:

1. Whitelisted Importer A in Iran places an order to buy $\mathrm{x}$ quantities of vital goods (food and medicine) produced by whitelisted European Exporter B (Operation 1)

2. With the delivery of goods satisfied, the SPV makes sure that European Exporter B receives euros from a European importer of whitelisted Iranian good (for instance, pistachios) (Operation 2)

3. The Iranian "mirror" SPV will work in a similar manner, assuming there will not be a trade deficit in its favor (Operation 3)

partners capable of clearing payments between Iranian importers and Iranian exporters for the same amounts. According to this logic, the European banks of European importers and exporters dealing with Iran will not be required to make or receive payments from Iran (see Figure 1). Thus, trade will proceed, with payments indirectly coordinated by two coordinated clearinghouses, in the hope that such a system would reduce the compliance costs for banks that follow with risk-based approaches to the humanitarian trade. 
INSTEX may to some degree insulate EU-Iran trade from US sanctions in the short or medium term, but shortcomings exist with the E3's current approach. First, a lack of coordination between the major powers across the Atlantic will inevitably raise the question of trust between regulatory superpowers. The European states involved have claimed that only European firms involved in the trade of vital goods (and not in the oil trade) will use INSTEX to avoid seeing INSTEX become a US sanctions target. Still, without a binding process that would tie the hands of OFAC to one commonly accepted definition of what constitutes humanitarian exemption, it remains an open question whether the United States will not target INSTEX and the European companies that use INSTEX to export vital and humanitarian goods. Second, even at the technical level, it is not clear whether INSTEX will solve the main problem for banks administering payments. The triangulation of payments organized by INSTEX will complicate the administration of KYC and KYCC s for European exporters of medicine (and their banks), who will need information not only on the Iranian importers of medicine to whom they send products (information they usually have), but also on the Iranian exporters of food whose deals with European importers will generate the money that will be sent to their accounts (information they lack). Furthermore, the mere fact that the Iranian "mirror SPV" has been created by the seven Iranian banks not designated by the US OFAC and the Central Bank of Iran (the latter a US-designated Iranian entity since late 2018) may doom the whole mechanism in the eyes of the US government, and thus for the European banks that may be tempted to use it. US Treasury undersecretary for terrorism and financial intelligence Sigal Mandelker has already expressed doubt about the ability of the Iranian side of the SPV to meet the norms of legitimate finance. ${ }^{48}$

Third, it is unclear how INSTEX will address the likely long-lasting trade imbalances between Europe and Iran that will result from the latest restrictions imposed by OFAC on all European imports of Iranian crude oil — with no more waivers extended to Italy and Greece after May 2019. A clearing mechanism works best over time if trade between each side is more or less balanced. The implication from the Iranian trade imbalance ${ }^{49}$ is that the Iranian trade firms will not be able settle the trade deficit with any European country or the EU without receiving loans from European countries, or using the proceeds gained from oil trade with other Asian countries, especially China. (See Figure 2 for details.) Thus, although it gives the appearance of a technical solution, INSTEX fails to rise to the political challenges of the times.

48 Murphy 2019.

49 Observatory of Economic Complexity, Massachusetts Institute of Technology 2019. 


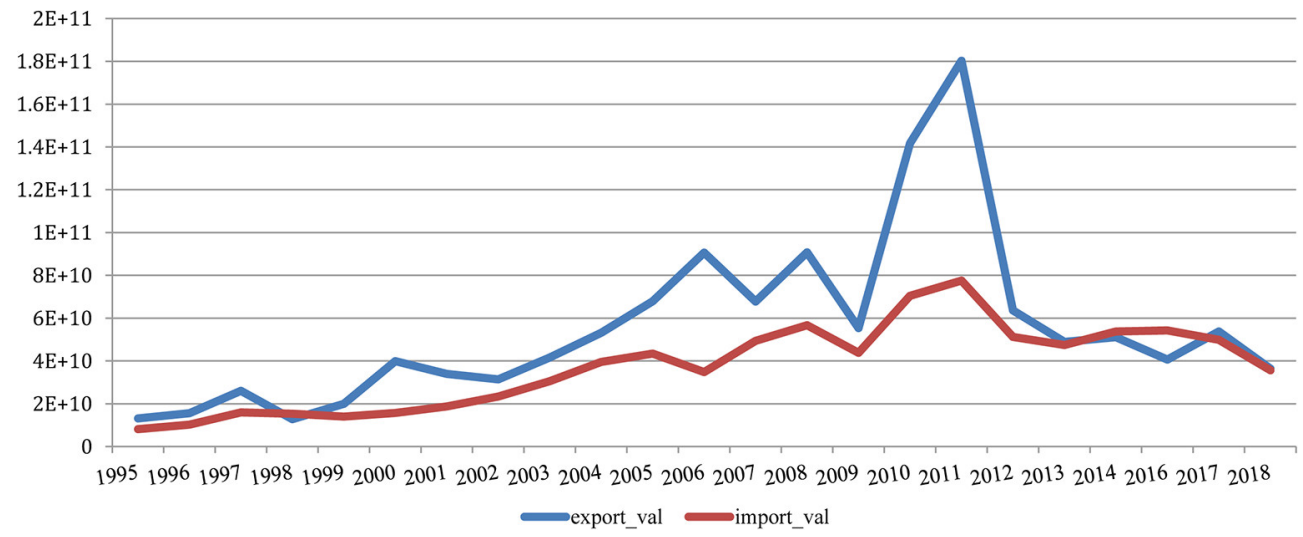

FIGURE 2 Trade balance between Iran and the world $\left(1995^{-2018}\right)($ red $=$ imports, blue $=$ exports)

Note: In the case of Iran, foreign trade is composed of three parts: (1) a constant trade surplus with the top four Asian economies (China, India, South Korea, and Japan), which contribute to go percent of Iranian export revenue through oil sales; (2) a constant trade deficit with any European Union (EU) country or the EU in general, of which only half is settled by Iranian exports to the EU, and the other half by a "transfer payment" using the proceeds of trade surplus with Asia; and (3) a general trade surplus with the rest of the world that contributes to the sizable scale of its foreign exchange (FX) reserves mostly held in European banks. As of 2017, Iran had a positive trade balance of US\$3.84 billion in net exports. As compared to its trade balance in 1995 when it still had a positive trade balance of $\$ 4.98$ billion in net exports. Source (of data in 1995-2017): "Iran (IRN) Exports, Imports, and Trade Partners," Observatory of Economic Complexity, Massachusetts Institute of Technology, atlas.media.mit.edu/en/profile/country/irn, in which data (1962-2000) is from The Center for International Data from Robert Feenstra at UC Davis at: http://cid.econ.ucdavis.edu/, and data (2001-2017) is provided by UN COMTRADE: http://comtrade.un.org/.

In the latest ten months from March 2018 to January 2019 (in the Iranian calendar), Iran managed to show a resistant foreign trade model that persisted a trade surplus for $\$ 678$ million at a cost of strict imports control (e.g., on cars confronting the currency crisis in the midst of sanctions coming back). Source (of data in 2018): Iranian Customs Administration (IRICA), http://www.irica.gov.ir/ news/1186817/1186817.htm (in Farsi; Iranian Trade Updates, accessed as of March 2019). 


\section{$4 \quad$ Facing the Power of OFAC: Toward a Myriad of Bilateral Solutions or a Coherent Multilateral Framework?}

Considering the shortcomings of present solutions to the humanitarian gap, some countries could be tempted to engage in a coordinated effort with the United States by seeking to tightly associate OFAC with their licensing procedures for all their exports of food and medicine to sanctioned jurisdictions. To the extent that non-US companies in the medical and food sectors depend on global banks to process their payments, and the latter look almost exclusively at OFAC's licensing regulations, OFAC's traditional practice of granting licenses only to companies exporting from the United States but not from elsewhere means giving US food and pharmaceutical companies an unfair advantage. Compared to European companies, the latter can petition OFAC to obtain a humanitarian license, which may (or may not) reassure a bank to then authorize payments, whereas the process was, until November 2019, out of reach for non-US companies that then found themselves incapable of reassuring their own banks on the conformity of payments coming from sanctioned jurisdictions with US law. In Europe, the Swiss government has opted in favor of such a direct bilateral approach with the United States and has thus far unsuccessfully requested an explicit waiver from OFAC for certain activities planned by Swiss companies in the fields of food and especially medicine, which represented about 6o percent of all Swiss exports to Iran in $2017 .{ }^{50}$ But the Swiss government has yet to obtain any authorization for specific exports, and Swiss companies may run into problems of giving too much information to a foreign power that has no specific reason to be involved in the administration of Swiss exports. ${ }^{51}$

Instead of granting Swiss companies a particular status under the US licensing scheme, OFAC has recently moved to open its exemption to all non-US companies in the vital trade sector in Iran, effectively claiming the role of global hegemon in the field of sanctions exemption. ${ }^{52}$ But the move may appear purely symbolic, and geared toward fending off criticisms that the US licensing system is the only one that matters for banks although it was, until November 2019, closed to non-US companies. Indeed, having OFAC approve every humanitarian transaction with Iran worldwide, screen monthly statements of financial entities involved in the transaction, and check the identity of the customers' customers, as required by the envisioned process of continued monitoring, will be a time-consuming and impractical task. OFAC exemptions can

$5^{\circ} \quad$ "Swiss Humanitarian Payment Channel with Iran 'Ready,' Awaits Capital" 2019.

$5^{1}$ Bozorgmehr 2018.

$5^{2}$ US Department of Treasury 2019. 
already take more than a year to obtain for US companies, so adding this new burden may over-burden the OFAC administration and may not even be sufficient to reassure non-US exporters and their banks that they do not risk legal consequences or commercial retaliation on their US operations, as sudden US policy shifts have occurred in the past, and the transparency requirement asked from Iranian importers of vital goods are much more intrusive than usually required even for "enhanced due diligence."

More importantly, from the political point of view, such a model, when scaled to the whole world, means that OFAC claims to be the sole authority in charge of administering a global oil for food and medicine program by which the Iranian economy and other sanctioned jurisdictions would obtain sanctions relief for their trade in vital goods. It is not clear if the US government will even support that hegemonic solution in the long-term, although precedents exist in other fields than sanctions law. As Adam Tooze aptly demonstrates, US financial regulators (in particular, the US Central Bank) endorsed global responsibilities when, in the middle of the 2008 crisis, the Fed effectively acted as the lender of last resort for European banks in distress and in desperate need of US dollars, which the Fed provided them either through domestic central banks or directly by exchanging bad securities against US Treasury bonds. As Tooze concludes, "What happened in the fall of 2008 was not a relativization of the dollar, but the reverse, a dramatic reassertion of the central role of America's central bank."53 The possibility that US financial authorities would agree to formally extend their jurisdiction from global central banking to global humanitarian licensing not only for humanitarian trade in Iran but in all sanctioned jurisdictions is thus not outside the bounds of possibility. But would other governments agree to let their private companies submit themselves to the authority of OFAC? Since the beginning of the Trump presidency, the EU and China have chaffed under perceived US infringement on their economic sovereignty, and they are not likely to endorse such a hegemonic form of governance by encouraging their private companies to apply to the new OFAC humanitarian mechanism.

In this context, a multilateral approach to sanctions exemption seems to be the only acceptable and effective solution to the humanitarian gap. A multilateral panel of Treasury officials of the Group of 20 (G-20; or G2O+, if a few exporters of medicine like Switzerland are to join) in which OFAC would be just one voice, would indeed help increase the acceptability of submitting the global trade in vital goods in Iran to a form of US screening, and eliminate the 
uncertainty over judicial litigation in the United States for non-US exporters of food and medicine trading in other sanctioned jurisdictions than Iran. Furthermore, one of its positive spin-offs would be to help G2O+ states to make progress in the harmonization of licensing codes. Licensing experts face hard questions, for example, whether medicine or Xray machines can be exported to sanctioned countries like Syria, independent of whether they might fall into the hands of designated governmental authorities, or whether such medical products can be exported only if exclusively used to treat civilians who are the victims of state repression. Not all nations see eye to eye on this issue. A new multilateral licensing organization would build consensus on these hard issues.

The US government may never agree to enter such a multilateral institution, especially in the present context marked by President Trump's general criticism of multilateralism. After all, the US Treasury plays this role without formally acknowledging it, thereby avoiding responsibility for negative humanitarian outcomes that can be traced back to its actions. Yet the United States' unwillingness to be more transparent about how it regulates global trade through sanctions is already accelerating desire among many states around the world to circumvent the US financial system and accelerate the process of dedollarization. Furthermore, US sanctions experts may see the creation of such a robust system as the only way to avoid breaking the US weapon of choice: targeted sanctions. For sanctions to remain targeted, and in a context of the comprehensivization of sanctions, there needs to be a multilateral institution capable of efficiently administering a global sanctions exemption program, either under a UN or G2O+ framework. This proposal would thus take away one of the main critiques of current US sanctions.

Still, it remains to be seen how banks would assess this proposal, and whether such a multilateral licensing authority would need to engage in the administration of payments as well, either in an indirect fashion like INSTEX, or in a more direct manner, to address the problem of banks' overcompliance with US sanctions. Considering present global uncertainties, global banks may stick to a zero-risk approach even after a G2O+ licensing organization is set up to regulate the global humanitarian trade. The latter could then also encourage "business-to-business payments" that rely, among other possibilities, on new digital financial technologies (FinTech), by creating a public-private partnership to process payments in the humanitarian trade. In fact, we argue that the creation of a blockchain-based Safecor coin would work to address other issues not tackled by other proposals.

The main idea behind the introduction of Safecor coins administered, for instance, by a G2O+ public-private partnership is that for those transactions between an entity located in a sanctioned jurisdiction and the outside world, if 
transactions were locked in a circuit of exchange denominated in the Safecor coin, that could only be used to buy vital goods abroad and that could be convertible only outside the sanctioned territory; for this lock-in feature, the management of KYC and KYT procedures in the Safecor coin would be much less costly than that denominated in a universal currency (like US dollar or Euro) and administered by multiple layers of banks. There is indeed an essential difference between non-fiat digital currencies and fiat currencies that is of primary relevance to the task at hand (see Appendix). Fiat currencies, such as the US dollar, euro, or Iranian rial, serve as a universal means of exchange and can thus be characterized as "dual-use": they can be used to buy anything and are found to circulate in the hands of good and bad actors alike. Sorting out whether euros or dollars come from OFAC-approved businesses means that global banks administering their circulation need to engage in costly KYC, KYCC, and KYT screening before authorizing each transaction.

Created as a single-purpose digital currency (SPDC), a Safecor coin, would facilitate the essential task of establishing a clean economic circuit when money flows in and out of a country under sanctions. The main task of the organization administering the Safecor coin would then be to authorize the new entities at the point of entry into the circuit, based on the decisions of the G2O+ licensing authority, and perform frequent but random controls on the payments patterns that are traceable on the digital ledger. ${ }^{54}$ The authorized entities would then exchange value by sending Safecor coins to one another according to the business-to-business payments scheme in accordance with the prescriptions of the World Bank Group.

In the case of Iran, it would mean that only the value generated by Iran's past OFAC-approved oil sales and future food and medicine sales would be locked in the circuit of Safecor coin exchange. Only Iranian entities authorized by the G2O+ licensing organization would be able to use the Safecor coin for buying food and medicine to approved entities. Compared to INSTEX, the adoption of such a Safecor coin would present many advantages (see Figure 3). First, it would create an economic circuit that is, by definition, limited to the trade of vital goods (see Table 4). Second, the circulation of Safecor coins would reassure all users of the coin that their transactions are preapproved ex ante by the OFAC and global regulators working in a G2O+ multilateral framework. Third, in line with the discussion above, it would create a balanced trade circuit.

54 Of course, Safecor coins would have to not be plagued by high volatility (see Appendix). 


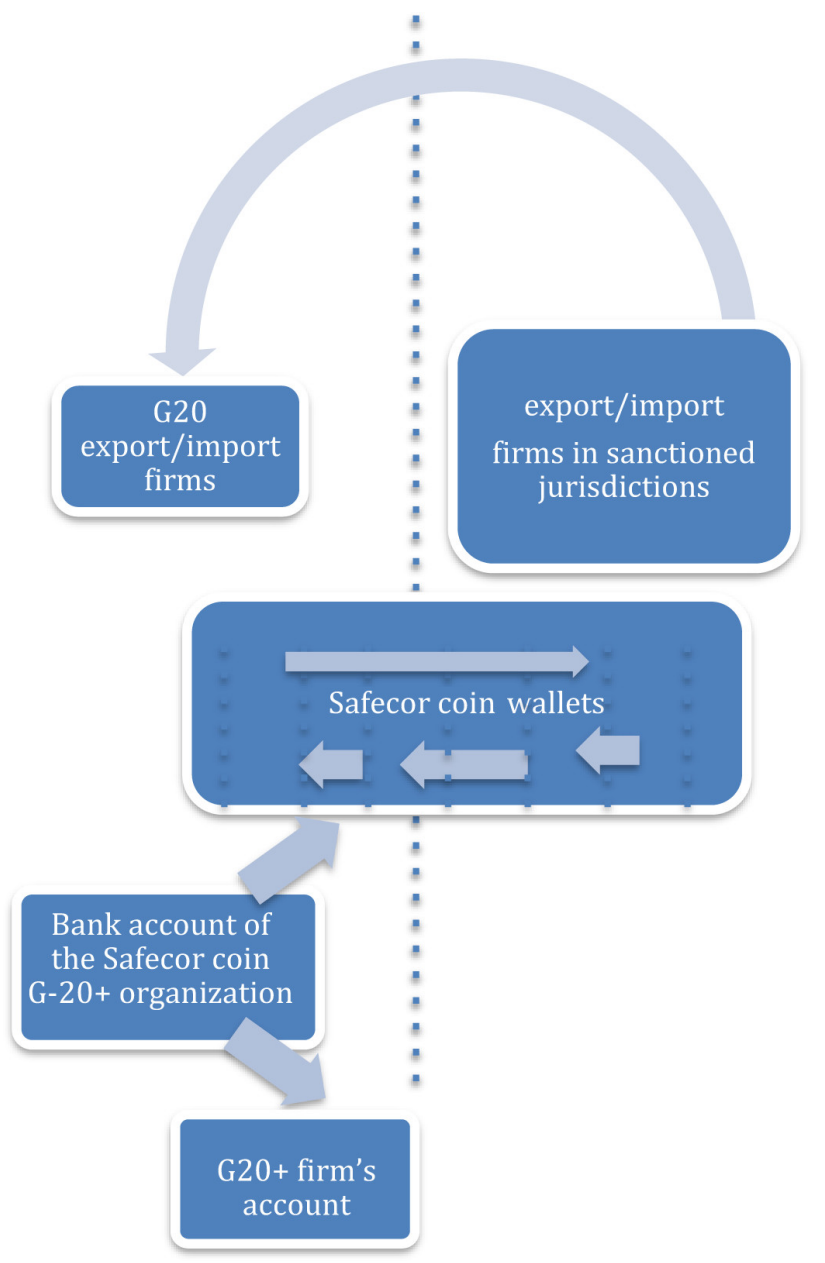

FIGURE 3 Safecor coin with and without Central Bank connection(s)

Note: Here are some explanations of how the system would work for Scenario 2; for instance, taking the example of Iran as far as sanctioned jurisdiction:

1. Whitelisted Importer A in Iran places an order to buy $\mathrm{x}$ quantities of goods produced by whitelisted European or G2O+ Exporter B (Operation 1)

2. With the delivery of goods satisfied, Exporter B receives Safecor coins (Operation 2)

3. At the end of each quarter, European and other Group of $20(\mathrm{G}-2 \mathrm{O})$ exporters are allowed to ask European or G-20 states to receive the equivalent of their accumulated Safecor coins in fiat money from their respective treasury (Operation 3) 
TABLE 4 The advantages of the Safecor coins versus special purpose vehicle (SPV)

Special purpose digital currency or Safecor coin

Locking-in effects:

Ensures that uses of the proceeds of oil for medicine and food programs are exclusively used for importing vital goods, lowering transaction costs and times

Low extraterritorial jurisdiction (ETJ) risks: The users do not worry about any future penalty by OFAC, as it is preapproved by OFAC,

- Either by OFAC only if the coin is administered by OFAC only

- Or by OFAC and other treasuries if the coin is administered by a multilateral organization

\section{Balanced trade:}

Combines trade flows from many participating states and sanctioned jurisdictions thereby ensuring greater sustainability

Cybersecurity:

- If it uses a centralized ledger, then more prone to hacking and disruption

- If it uses the blockchain, a decentralized digital ledger technology (DLT) ensures greater defense against hacking and disruption
Special purpose vehicle (INSTEX)

No locking-in effects:

Does not ensure that the fiat money used to buy vital goods comes from Office of Foreign Assets Control (OFAC)-approved transactions, thus requiring the most costly Know Your Customer (KYC), anti-money laundering (AML), and counterterrorism financing (CTF) compliance and due diligence procedures for each transaction

High contingent ETJ risks:

Today's users are fully exposed to such contingent penalty risks from the trade settlements, now presumed to be compliant by the European Union (EU) standard, but later possibly considered as a violation by OFAC or New York Dept. of Financial Services

Trade imbalance:

Fewer participants and mismatch between import and export flows result in chronic deficits and decrease sustainability

Cybervulnerability:

Centralized ledger means it is more prone to hacking and disruption 
TABLE 4 The advantages of the Safecor coins versus special purpose vehicle (SPV) (cont.)

\section{Special purpose digital currency or Safecor Special purpose vehicle (INSTEX)} coin

Global standard for vital goods trade:

- If it is administered by OFAC, then it will unify the field around US views on humanitarian exemptions, which may lead to contestation

- If it is administered by a multilateral organization, it can create convergence around basic compliance standard for vital goods trade with positive humanitarian outcomes
Fragmented standard vital goods trade: Promotes conflict and competition and politicizes trade in vital goods with negative humanitarian outcomes

There are at least three technical reasons to favor a Safecor coin administered by a G2O+ authority over the creation of a new SPDC run by one government only, like the US government. First, new blockchain-based digital ledger technologies (DLTs) allow remote and traceable peer-to-peer transfer of electronic value in the absence of trust between transacting parties, by greatly enhancing transparency, as illustrated by its applications in global value chains, or in humanitarian camps. ${ }^{55}$ Second, as all payments are recorded in a constantly updated decentralized ledger that protects anonymity of its users, issues of privacy and limits to the information for governments could be addressed in a way that the creation of a centralized ledger cannot. Third, a decentralized ledger would ensure greater defense against hacking and disruption than a centrally located ledger.

\section{5}

\section{Conclusion}

Taking the example of Iran, our article has focused on identifying the source of problems encountered by global banks in the trade of humanitarian and vital goods with sanctioned jurisdictions. We argue that the creation of a new multilateral organization in charge of administering such payments using new digital currencies (the Safecor coin) within a network of strictly authorized

55 Hempel 2018. 
entities can provide a technically feasible, politically acceptable, and economically sustainable solution to the main problems that countries under sanctions face when trying to import vital goods. This political and technical solution addresses the general problem of coordination between actors who are all ostensibly committed to the continuation of trade of vital goods in sanctioned jurisdictions, but take contradictory approaches. Unlike the SPV like INSTEX or any universal currency like the US dollar or Euro, the creation of the new SPDC also resolves the problems of trust, trade balances, and transaction costs. This latter point is particularly important.

Our article aims to initiate dialogue between the diplomatic, humanitarian, and financial technology communities to develop FinTech solution(s) that address the problems of humanitarian finance and resolve pressing policy issues. The diplomatic community stands to gain through the availability of more tools to formulate solutions to policy problems. Meanwhile, the humanitarian sector will be less constrained to fulfill its mission in sanctioned jurisdictions if new solutions that move beyond the hegemonic solution proposed by the US government in the case of Iran are tested. If blockchain and other digital payment systems can enable creative solutions to the most pressing problems plaguing the international trade of vital goods today, it is urgent to bring these insights to the policy-makers who are responsible for the implementation of sanctions.

\section{Acknowledgments}

This project received funding from the European Research Council under the European Union's Horizon 2020 research and innovation program (Grant Agreement PROSANCT, "Bombs, Banks and Sanctions," Project 716216) headed by Grégoire Mallard. The authors thank all the interviewees who participated in the research, and the following individuals for their comments: Esfandyar Batmanghelidj, Thomas Biersteker, Pascal Daudin, Christian Gianella, Francesco Giumelli, Erica Moret, Richard Nephew, Nicholas Niggli, and Michal Onderco. The authors are solely responsible for the content of this article. Address all correspondence to Grégoire Mallard. 


\section{Bibliography}

Batmanghelidj, Esfandyar. "Europe Protects Itself from Trump's Caprice." Bloomberg, 31 January 2019. https://www.bloomberg.com/opinion/articles/2019-01-31/with-itsiran-spv-europe-protects-itself-from-american-caprice.

Batmanghelidj, Esfandyar, and Axel Hellman. "Mitigating US Sanctions on Iran: The Case for a Humanitarian Special Purpose Vehicle." European Leadership Network, 28 November 2018. https://www.europeanleadershipnetwork.org/policy-brief/mitig ating-us-sanctions-on-iran-the-case-for-a-humanitarian-special-purpose-vehicle/.

Biersteker, Thomas J., and Sue E. Eckert. Countering the Financing of Terrorism (London: Routledge, 2008).

Biersteker, Thomas J., Sue E. Eckert, and Marcos Tourinho. 2016. Targeted Sanctions: The Impacts and Effectiveness of United Nations Action (Cambridge: Cambridge University Press, 2016).

Borger, Julian, and Saeed Kamali Dehghan. "US Rebuffs Europeans over Ensuring Iran Sanctions Exempt Food and Medicine." The Guardian, 2 November 2018. www .theguardian.com/world/2018/nov/o2/iran-sanctions-us-european-humanitarian -supplies.

Bozorgmehr, Najmeh. "Switzerland Prepares to Launch Iran Payments Channel." The Financial Times, 19 December 2018. www.ft.com/content/21913614-o2e3-11e9-99df -6183 d3ooreel.

Brzoska, Michael. "From Dumb to Smart? Recent Reforms of UN Sanctions." Global Governance, 9 (4) 2003, pp. 519-535.

Charity and Security Network. "Safeguarding Humanitarianism in Armed Conflict." June 2012. http://www.charityandsecurity.org/sites/default/files/Safeguarding\%2O Humanitarianism\%2oFinal.pdf.

Congressional Research Service. "Iran Sanctions." 2019. https://fas.org/sgp/crs/mideast/ RS20871.pdf.

Corazza, Carlo. “The World Bank's Data Gathering Efforts: De-Risking? Key Findings and Recommendations." World Bank, January 2016. http://pubdocs.worldbank.org/ en/953551457638381169/remittances-GRWG-Corazza-De-risking-Presentation-Jan2 o16.pdf.

Cortright, David, and George Lopez, eds. The Sanctions Decade: Assessing UN Strategies in the 1990s (Boulder: Lynn Rienner, 2000).

Crow, David. "Ex-Standard Chartered Banker Prepares to Plead Guilty in Iran Case." The Financial Times, 13 January 2019. www.ft.com/content/32adgcbc-1729-11e9-9e64 $-\mathrm{d}_{5} \mathrm{ob}_{3105} \mathrm{~d} 21$.

Department of Justice. "United States District Court Southern District of New York-v.BNP Paribas, S.A.” 2014. https://www.justice.gov/sites/default/files/.../2014/.../infor mation.pdf. 
Djelic, Marie-Laurie, and Kerstin Sahlin Andersson. "A World of Governance." In Transnational Governance, eds. Marie-Laure Djelic and Kerstin Sahlin-Andersson (Cambridge: Cambridge University Press, 2006), 1-30.

Drezner, Daniel W. The Sanctions Paradox: Economic Statecraft and International Relations (Cambridge: Cambridge University Press, 1999).

Eckert, Sue, Kay Guinane, and Andrea Hall. "Financial Access for US Nonprofits." Charity and Security Network, 2017. https://www.charityandsecurity.org/system/files/Fin ancialAccessFullReport_2.21\%2O(2).pdf.

Erbenová, Michaela, Yan Liu, Nadim Kyriakos-Saad, Aledjandro Lopez Mejia, Jose Giancarlo Gasha, Emmanuel Mathias, Mohamed Norat, Francisca Fernando, and Yasmin Almeida. "The Withdrawal of Correspondent Banking Relationships: A Case for Policy Action." IMF Staff Discussion Note (Washington, DC: International Monetary Fund, June 2016). https://www.imf.org/external/pubs/ft/sdn/2016/sdn16o6.pdf.

Farzanegan, Mohammad Reza, Mohammad Mohammadikhabbazan, and Hossein Sadeghi. "Effects of Oil Sanctions on Iran's Economy and Household Welfare: New Evidence from a CGE Model." In Economic Welfare and Inequality in Iran:Developments since the Revolution, eds. Mohammad Reza Farzanegan and Pooya Alaedini (Palgrave Macmillan, 2016), 185-211.

Financial Action Task Force. "FATF Takes Action to Tackle De-Risking." 23 October 2015. http://www.fatf-gafi.org/publications/fatfrecommendations/documents/fatf -action-to-tackle-de-risking.html.

Financial Stability Board. "FSB Correspondent Banking Data Report." 4July 2017. http:// www.fsb.org/2017/o7/fsb-correspondent-banking-data-report/.

Ghalibafian, Mithra, Shabnam Hemmati, and Eric Bouffet. "The Silent Victims of the US Embargo against Iran.” The Lancet Oncology, Volume 19 (2018), Issue 11, Page e58o.

Hafezi, Parisa. "Iran Says France's Total Has Officially Left South Pars Deal:TV." Reuters, 20 August 2018. www.reuters.com/article/us-iran-france-total/iran-says-frances-tot al-has-officially-left-south-pars-deal-tv-idUSKCN1L5oPH.

Hempel, Jessi. "How Refugees Are Helping Create Blockchain's Brand New World." Wired, 23 April 2018. www.wired.com/story/refugees-but-on-the-blockchain/.

Hufbauer, Gary Clyde, Jeffrey J. Schott, and Kimberly Ann Elliott. Economic Sanctions Reconsidered: History and Current Policy. (Washington, DC: Institute for International Economics, 1990).

International Stakeholder Dialogue. "Report on Ensuring Financial Services for Nonprofit Organizations" (The Hague: February 2018). FATF Platform (The Global NPO Platform on FATF), February 15, 2018. http://fatfplatform.org/announcement/ international-stakeholder-dialogue-ensuring-financial-services-non-profit-organi zations/; http://files.acams.org/pdfs/2018/Background-Paper-(oo2).pdf; http://fatf platform.org/wp-content/uploads/2018/o2/Ensuring-Financial-Access-for-Non 
-profit-Organizations_Final-Report.pdf; http://fatfplatform.org/wp-content/ uploads/2018/o2/Background-Paper-1.pdf

Kheirandish M., Varahrami V., Kebriaeezade A., Cheraghali A.M. Impact of economic sanctions on access to noncommunicable diseases medicines in the Islamic Republic of Iran. East Mediterranean Health Journal. 2018; 24 (1):42-51.

Kurmanaev, Anatoly, and Clifford Krauss. "U.S. Sanctions Are Aimed at Venezuela's Oil: Its Citizens May Suffer First." The New York Times, 8 February 2019. https://www .nytimes.com/2019/o2/o8/world/americas/venezuela-sanctions-maduro.html.

Mallard, Grégoire. "Governing Proliferation Finance: Multilateralism, Transgovernmentalism and Hegemony in the Case of Sanctions Against Iran." In Oxford Handbook of Institutions of International Economic Governance and Market Regulation, eds. Eric Brousseau, Jean-Michel Glachant and Jérôme Sgard (Oxford: Oxford University Press, 2019). DOI: 10.1093/oxfordhb/9780190900571.013.20

McDowall, Angus. "Long Reach of U.S. Sanctions Hits Syria Reconstruction." Reuters, 6 September 2018. https://www.reuters.com/article/us-mideast-crisis-syria-sanctio ns-idUSKCN1LIo6Z.

Motevalli, Golnar, and Ladane Nasseri. “Trump's Sanctions Are Proving a Bitter Pill for Iran's Sick." Bloomberg, 21 November 2018. www.bloomberg.com/news/articles/2018 -11-21/trump-s-sanctions-are-proving-a-bitter-pill-for-iran-s-sick.

Murphy, Francois. "EU-Iran Trade Vehicle Unlikely to Meet Anti-Money-Laundering Norms: U.S." Reuters, 7 May 2019. www.reuters.com/article/us-usa-iran-sanctions/ eu-iran-trade-vehicle-unlikely-to-meet-anti-money-laundering-norms-u-s-idUSKC NiSD24L.

National Iranian American Council. "Letter to Pompeo on Iran Sanctions \& Humanitarian Exemptions.” 21 December 2018. www.niacouncil.org/letter-pompeo-iran-sancti ons-humanitarian-exemptions/.

Nephew, Richard. The Art of Sanctions: A View from the Field (New York: Columbia University Press, 2018).

Observatory of Economic Complexity, Massachusetts Institute of Technology. "Iran (IRN) Exports, Imports, and Trade Partners.” 2019. atlas.media.mit.edu/en/profile/c ountry/irn.

Pape, Robert. "Why Economic Sanctions Do Not Work." International Security 22 (2) (1997), 90-136.

Protess, Ben, and Jessica Silver-Greenberg. "HSBC to Pay \$1.92 Billion to Settle Charges of Money Laundering." The New York Times, 1o December 2012.

Qiblawi, Tamara, Frederik Pleitgen, and Claudia Otto. "Iranians Are Paying for US Sanctions with Their Health." CNN, 22 February 2019. https://edition.cnn.com/2019/o2/ 22/middleeast/iran-medical-shortages-intl/index.html.

Saul, Jonathan. "Exclusive: Global Traders Halt New Iran Food Deals as U.S. Sanctions Bite." Reuters, 21 December 2018. www.reuters.com/article/us-iran-nuclear-food-exc lusive-idUSKCNiOKıOR. 
Serrano, Monica, and Paul Kenny. "The International Regulation of Money Laundering." Global Governance 9 (4) (2003), 433-439.

Sharafedin, Bozorgmehr. "Iran Approves Anti-Money Laundering Bill to Ease Foreign Investment." Reuters, 5 January 2019. https://www.reuters.com/article/us-iran-econ omy-fatf/iran-approves-anti-money-laundering-bill-to-ease-foreign-trade-idUSKC $\mathrm{NiOZoBW.}$

Slaughter, Anne-Marie. A New World Order (Princeton: Princeton University Press, 2004).

Solingen, Etel, ed. Sanctions, Statecraft and Nuclear Proliferation (Cambridge: Cambridge University Press, 2012).

Sregantan, Navin. "Hyflux Suspends Contract for Desalination Package in Iran." The Business Times, 14 December 2018. www.businesstimes.com.sg/companies-markets /hyflux-suspends-contract-for-desalination-package-in-iran.

“Swiss Humanitarian Payment Channel with Iran 'Ready,' Awaits Capital." Iran Chamber of Commerce, 1o March 2019. http://en.otaghiranonline.ir/news/11786.

Tooze, Adam. Crashed: How a Decade of Financial Crises Changed the World (New York: Allen Lane, 2018).

United States Department of the Treasury. "Treasury and State Announce New Humanitarian Mechanism to Increase Transparency of Permissible Trade Supporting the Iranian People," US Department of Treasury, October 25, 2019. https://home.treasury .gov/news/press-releases/sm8o4

George Weiss, David Cortright, George A. Lopez, and Larry Minear. Political Gain and Civilian Pain: Humanitarian Impacts of Economic Sanctions (Lanham, MD: Rowman and Littlefield, 1998).

World Bank. "Report on the G2o Survey in De-Risking Activities in the Remittance Market." 2015. http://documents.worldbank.org/curated/en/679881467993185572/Repor t-on-the-G2O+-survey-in-de-risking-activities-in-the-remittance-market.

World Bank. "De-Risking in the Financial Sector." 7 October 2016. www.worldbank.org/ en/topic/financialsector/brief/de-risking-in-the-financial-sector.

World Food Programme. "WFP DPR Korea Country Brief." 1 February 2019. https://docs .wfp.org/api/documents/WFP-oooo1o2744/download/.

Wroughton, Lesley, and Steve Holland. "U.S. Ratchets up Pressure on Iran with Resumption of Sanctions." Reuters, 5 November 2018. https://www.reuters.com/article/us -usa-iran-sanctions/u-s-ratchets-up-pressure-on-iran-with-resumption-of-sanctio ns-idUSKCNiNAoDJ.

Zarate, Juan Carlos. Treasury's War: The Unleashing of a New Era of Financial Warfare (New York: PublicAffairs, 2015). 


\section{Appendix: Generations of Ledger Technologies and Outstanding Issues}

From a technological point of view, we can roughly differentiate the world of banking and nonbanking as following various stages, from the traditional world of global banking (Stage $\mathrm{o}$ ) - with its operations through paper letters of credit and other centralized systems of cross-border clearance, through correspondent banking - to the most recent developments in cryptocurrencies (see Table Ar). What we call Stage o is represented by the complex ecosystem of global banking solutions for trade settlement and encompasses not only leading private banks, but also any special purpose vehicle (SPV). Relying on payments through the existing global commercial banks or SPVs does not mean that the system is not also vulnerable to money laundering and sanctions evasion. Since the early 2010s, the evolution in the world of digital currencies has been stark. New FinTech solutions appear almost monthly. First-generation cryptos are best represented by Bitcoin, which provides a concrete example of a nonbanking money transfer service on the basis of publicly recorded blockchain technology. Each transaction is recorded and replicated on this DLT, which is maintained by a network of mutually distrustful parties, referred to as "miners" for Bitcoin. The miners get small rewards for maintaining the virtual ledger, typically fractions of Bitcoins when they succeed in adding a block of transactions to the blockchain. The DLT keeps all records and is publicly available, allowing everyone to review all transactions, although in an anonymized fashion, as the wallet holders protect their privacy thanks to the most up-to-date advancements in cryptography. Such blockchain-based digital currencies aim at replicating peer-to-peer transactions based on fiat money without the centralized authority of a trusted intermediary, usually a bank, or another fiduciary entity, such as a central notary whose role is to centralize the clearing of payments between clients-for instance, the SPV backed by the three European countries (EU-3/France, Germany and the UK). The decentralized character of the blockchain means that recorded transactions cannot be altered - hence, its transparency-enhancing character-and it cannot be hacked in its entirety - thereby, better protecting the privacy of wallet holders compared to a recording system of payments administered by a central notary.

From Bitcoin, new blockchain-based digital currencies have developed different features based on this basic DLT architecture. In particular, a second generation of currencies modeled after Ethereum (ETH) includes technologies to preregister transactions that will be completed if certain conditions are met. They make it possible to register "smart contracts," which typically consist of commands to execute a payment in the future, provided the payee has ful- 
TABLE A1 Generations of ledger technologies

$\begin{aligned} & \text { Generation } \\ & \text { of payment }\end{aligned}$
systems

O.O

BNP Paribas Global reach

1.0

Bitcoin

ETH

Tether

4.0

Safecor
Nonbanking, but traceable and publicly recorded

ICO by smart contracts, feasibility to high speed

Low volatility by US dollar asset-backed tokenization, instant speed by exchange

AML/counterterrorism financing (CTF)/ counterproliferation financing (CFP) compliant, trade finance functions, and low volatility; no SWIFT, isolated from host country and Iranian banking system
SWIFT, host country, AML

(settlement with Iranian banks)

High volatility, initial coin offering (ICO) by mining, antimoney laundering (AML), too low speed of settlement for any real business application

High volatility, AML

Significantly high risks in AML

No listing in any exchange, no liquidity in secondary market, and no access for any public users except for whitelisted users

filled their part of the contract. Furthermore, Ethereum improves on Bitcoin by avoiding electricity-wasting coin mining, as it provides a fixed quantity of coins through an ICO. But like Bitcoin, it is also traded on public exchange platforms (e.g., Binance, etc.), which addresses the problem of the low speed of payments settlements, but raises AML concerns, as these exchange platforms follow lax Know your Customer (KYC) rules. Finally, as the maximum coin supply of Bitcoin and Ethereum is fixed, price volatility remains a strong feature, particularly when speculative money rushes into the market, alongside hackers who engage in market manipulation and theft. This is why a third-generation of dig- 
ital currencies, known as stable coins (e.g., Tether or USDT) use asset-backed securities (ABS) from modern finance and apply it to the digital world to solve the volatility problem afflicting Bitcoin and Ethereum. Third-generation digital coins quickly became highly traded on the market (USDT was the fifth most traded cryptocurrency by the end of 2018) because it is pegged to the US dollar. 